\title{
Vitamin D deficiency in elderly people in Swedish nursing homes is associated with increased mortality
}

\author{
Maria Samefors, Carl Johan Östgren, Sigvard Mölstad', Christina Lannering², \\ Patrik Midlöv' ${ }^{\mathbf{1}}$ and Anders Tengblad ${ }^{2}$ \\ Department of Medical and Health Sciences, Linköping University, SE-581 83 Linköping, Sweden, \\ ${ }^{1}$ Department of Clinical Sciences Malmö, Lund University, Malmö, Sweden and ${ }^{2}$ Unit of Research and Development \\ in Primary Care, Futurum, Jönköping, Sweden
}

Correspondence

should be addressed

to M Samefors

Email

maria.samefors@lj.se

\begin{abstract}
Objective: Institutionalised elderly people at northern latitudes may be at elevated risk for vitamin D deficiency. In addition to osteoporosis-related disorders, vitamin $D$ deficiency may influence several medical conditions conferring an increased mortality risk. The aim of this study was to explore the prevalence of vitamin $D$ deficiency and its association with mortality. Design: The Study of Health and Drugs in the Elderly (SHADES) is a prospective cohort study among elderly people (>65 years) in 11 nursing homes in Sweden.

Methods: We analysed the levels of 25 -hydroxyvitamin $\mathrm{D}_{3}\left(25(\mathrm{OH}) \mathrm{D}_{3}\right)$ at baseline. Vital status of the subjects was ascertained and hazard ratios (HRs) for mortality according to $25(\mathrm{OH}) \mathrm{D}_{3}$ quartiles were calculated.

Results: We examined 333 study participants with a mean follow-up of 3 years. A total of 147 (44\%) patients died within this period. Compared with the subjects in Q4 $\left(25(\mathrm{OH}) \mathrm{D}_{3}>48 \mathrm{nmol} / \mathrm{l}\right)$, $\mathrm{HR}$ (with $\left.95 \% \mathrm{Cl}\right)$ for mortality was $2.02(1.31-3.12)$ in Q1 $\left(25(\mathrm{OH}) \mathrm{D}_{3}<29 \mathrm{nmol} / \mathrm{l}\right)(P<0.05) ; 2.03(1.32-3.14)$ in Q2 $\left(25(\mathrm{OH}) \mathrm{D}_{3} 30-37 \mathrm{nmol} / \mathrm{l}\right)(P<0.05)$ and $1.6(1.03-2.48)$ in Q3 $(25(\mathrm{OH})$ $\left.\mathrm{D}_{3} 38-47 \mathrm{nmol} / \mathrm{l}\right)(P<0.05)$. The mean $25(\mathrm{OH}) \mathrm{D}_{3}$ concentration was $40.2 \mathrm{nmol} / \mathrm{l}($ s.D. 16.0$)$ and $80 \%$ had $25(\mathrm{OH}) \mathrm{D}_{3}$ below $50 \mathrm{nmol} / \mathrm{l}$. The vitamin $D$ levels decreased from baseline to the second and third measurements.

Conclusions: Vitamin D deficiency was highly prevalent and associated with increased mortality among the elderly in Swedish nursing homes. Strategies are needed to prevent, and maybe treat, vitamin D deficiency in the elderly in nursing homes and the benefit of vitamin $D$ supplementation should be evaluated in randomised clinical trials.
\end{abstract}

\section{Introduction}

Vitamin $\mathrm{D}$ is a fat-soluble vitamin with hormonal qualities. The two sources of vitamin D are food and sunlight, of which sunlight accounts for more than $90 \%$ of the body's vitamin D supply (1). Vitamin D is produced in the skin under the influence of u.v. B light, which at our northern latitudes in Sweden is only available during a few hours around lunchtime in the summer months $(2,3)$.

It is well-known that a severe vitamin D deficiency leads to rickets and osteomalacia. Vitamin D deficiency is also a risk factor for osteoporosis, falls, fractures and muscle weakness (4), and several other studies have shown an association between low levels of vitamin D and an increased risk of fractures $(5,6,7,8)$, falls (9), cardiovascular disease $(1,10,11,12,13,14)$ and mortality $(15,16,17,18,19,20,21,22,23)$. A meta-analysis of randomised trials of the effects of vitamin D supplementation has shown a modest decrease in the mortality rate predominantly in elderly women with low levels of vitamin D (24).

A recent study has shown that vitamin D levels above $90 \mathrm{nmol} / \mathrm{l}$ also were associated with an increased (c) 2014 European Society of Endocrinology Printed in Great Britain
Published by Bioscientifica Ltd. 
mortality (25). However, it was only a small sample of the study population that had high vitamin D levels, and the increase in mortality risk and acute coronary syndrome events in this group were modest compared with the risks in the groups with low vitamin D levels. This finding has led to a discussion about what shape of curve most closely illustrates the association between levels of vitamin $D$ and outcome (26). Thus, the optimum level of vitamin D is not yet clearly defined. Serious deficiency is considered to exist at levels of 25-hydroxyvitamin D (25(OH)D) below $25 \mathrm{nmol} / \mathrm{l}$, due to its association with rickets and osteomalacia. The levels between 25 and $50 \mathrm{nmol} / \mathrm{l}$ are categorised as insufficiency, as $50 \mathrm{nmol} / \mathrm{l}$ is the lowest level that prevents secondary hyperparathyroidism, increased bone turnover, bone mineral loss or seasonal variations in plasma parathyroid hormone (PTH) (27).

People living at northern latitudes are at risk for vitamin D deficiency during the winter $(2,3)$. Subjects at elevated risk for vitamin D deficiency are those with insufficient sun exposure, the elderly, dark-skinned people living at northern latitudes, people with clothes covering much of their body, vegans and individuals who do not eat fish or dairy products (28). Elderly people in nursing homes could be at risk for vitamin D deficiency because they have a limited exposure to sun, often eat less food and because the cutaneous synthesis of vitamin D decreases with increased age. The metabolism of vitamin $\mathrm{D}$ remains relatively normal in elderly people, but the renal formation of $1.25(\mathrm{OH})_{2} \mathrm{D}$ can be restricted by impaired renal function and chronic diseases $(27,29)$.

Several international studies have shown that vitamin D deficiency is highly prevalent in the elderly $(23,30,31,32,33,34,35)$. A few relatively small Scandinavian studies found that vitamin D deficiency was common, especially in elderly people living in homes for the aged $(30,31)$. A prospective cohort study among elderly female patients in nursing homes in Austria showed that vitamin D deficiency was highly prevalent and that there was an association between low levels of vitamin $\mathrm{D}$ and an increased risk of mortality (23). There are, to our knowledge, no Northern European studies about vitamin D deficiency and mortality risk in elderly people living in nursing homes.

The aim of this study was to examine whether lower levels of vitamin D were associated with an increased risk of mortality in elderly people in Swedish nursing homes. Furthermore, our aim was to explore the prevalence of vitamin D deficiency, how the levels of vitamin D changed over time and to examine if lower levels of vitamin D were associated with an increased risk of cardiovascular events, falls or fractures.

\section{Subjects and methods}

The Study of Health and Drugs in the Elderly (SHADES) is a cohort study conducted in 11 nursing homes in three cities in southern Sweden: Eslöv, Jönköping and Linköping. Nursing homes were defined as homes for elderly people with collective living areas and collective nursing staff. The aim of SHADES was to describe and analyse mortality, morbidity, health status and the use of medication among people living in nursing homes. The study was conducted between 2007 and 2011. New patients were included until March 2011. Analysis of deceased people was conducted in March 2012. All the residents at the start of the study and all persons who moved into the selected nursing homes were invited to participate. Exclusion criteria were as follows: planned short-term stay, for example, for rehabilitation or palliative care, language difficulties and age under 65 years. Consent has been obtained from each subject after full explanation of the purpose and nature of all procedures used. This study was approved by the Regional Ethical Review board at Linköping University, number: M150-07.

\section{Measurements}

Participants were consecutively included at six occasions as new subjects moved into the nursing homes. The following were registered: age, gender, the date of moving into the nursing home, the date of inclusion in the study and the date of leaving the nursing home or death. Every 6 months, specially trained nurses performed examinations and collected data from the county's medical records about diagnoses, chronic diseases, current medication and information concerning acute events during the last 6-month period in the nursing home. The number of visits to general practitioners (GP) and emergency wards and occurrences of hospitalisation as well as resulting diagnoses was recorded from the medical records. According to diagnosis, the visits caused by cardiovascular events, falls or fractures were classified and counted. A fall was defined as a fall causing a visit to the GP, emergency ward or hospitalisation but without fractures. The causes of death including the total number of fatal cardiovascular events were ascertained from the death certificates. To estimate the functional level of the subjects, we used the second-subscale, named physical activity in the modified Norton scale (MNS) (36), performed at inclusion 
in the study. The item is assessed with a range from 1 (lack of function) to 4 (normal function): 1 , bedridden; 2 , chairbound (all day); 3, walks with help (wheelchair when independent transportations); and 4, ambulant. From the Downton Fall Risk Index (DFRI) (37), performed at inclusion in the study, history of known falls during the last year (yes or no) was noted, also including falls not leading to medical care.

At inclusion in the study, the subject's weight was measured to the nearest kilogram and the height to the nearest centimetre. BMI was calculated from the weight in kilograms divided by the square of the height in metres. The blood pressure was recorded three times in sitting position and the mean value was used for analyses.

\section{Laboratory methods}

Fasting blood samples were collected and frozen for later analyses. The levels of $25(\mathrm{OH}) \mathrm{D}_{3}$ were analysed in serum on three occasions with a 1 year interval: at inclusion and after 1 and 2 years. All blood samples were analysed at the Department of Clinical Chemistry, County Hospital of Ryhov, Jönköping, Sweden, with HPLC technology. Following extraction, separation of $25(\mathrm{OH}) \mathrm{D}_{3}$ was carried out by HPLC-System (reagent kit and HPLC column from Chromsystems Instruments \& Chemicals GmbH, Munich, Germany) with u.v. detection at a wavelength of $265 \mathrm{~nm}$ (u.v. detector from Dionex ThermoFisher Scientific, Inc., Sunnyvale, CA, USA). The lowest detection limit was $6.0 \mathrm{nmol} / 1$ and the measuring interval was 6-1250 nmol/l.

Haemoglobin, creatinine and cystatin $\mathrm{C}$ were analysed at inclusion in the study. Glomerular filtration rate (GFR) was estimated by cystatin C (eGFR) in $\mathrm{ml} / \mathrm{min}$ per $1.73 \mathrm{~m}^{2}$ and was calculated as: $\mathrm{eGFR}=84.69 \times\left(1 /\right.$ cystatin $\left.\mathrm{C}^{1680}\right)(38)$.

\section{Statistical analyses}

Statistica 10 (StatSoft, Inc., Tulsa, OK, USA) was used for the statistical analyses. Comparisons between groups were performed with $t$-test and ANOVA. Differences between proportions were calculated with $\chi^{2}$-test. Correlation between two variables was calculated with Spearman's rank correlation. Cox regression analyses were used to calculate hazard ratios (HRs) for mortality in the different $25(\mathrm{OH}) \mathrm{D}_{3}$ quartiles, with the fourth quartile as a reference. Logistic regression analyses were used to calculate odds ratio for cardiovascular events, falls and fractures in the different $25(\mathrm{OH}) \mathrm{D}_{3}$ quartiles, with the fourth quartile as a reference.

\section{Results}

From the total number of participants in SHADES $(n=429), 96$ were excluded from the analyses: $55(14 \%)$ for being on vitamin $\mathrm{D}$ medication in combination with calcium and 41 for lacking data (Fig. 1). Thus, 333 subjects remained for further analyses in this study and were categorised into four quartiles according to their $25(\mathrm{OH}) \mathrm{D}_{3}$ levels at inclusion. Baseline characteristics of the study population are shown in Table 1 . Of the participants, 226 (68\%) were women and 107 (32\%) men. Mean age for the women was 86 years and for the men 83 years. There was a difference in age between Q1 and Q4 for men, but no differences in age were seen between the quartiles for women. The proportion of Q4 that had lived $<1$ year in the nursing home at inclusion was larger than in Q1 $(P=0.05)$, but otherwise no differences were seen between the quartiles in time spent in the nursing homes. There was no difference in BMI, haemoglobin levels, blood pressure or levels of physical activity between the quartiles. There was a difference in creatinine levels between Q1 and Q3 $(P<0.05)$, and for women also between Q1 and Q4 $(P<0.05)$. However, no

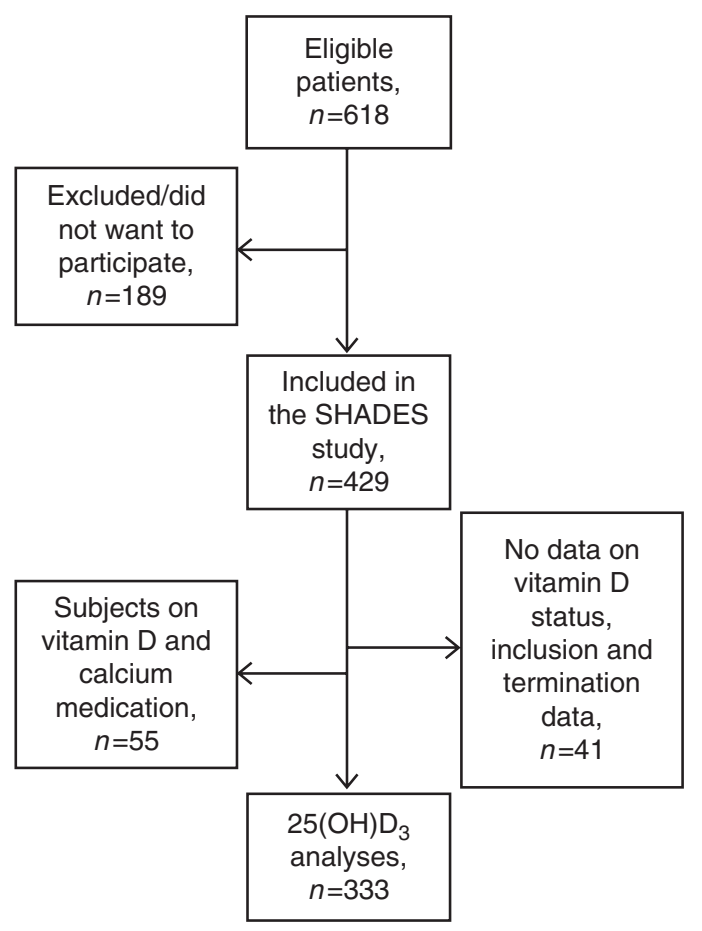

\section{Figure 1}

Flow chart of the patients in the Study of Health and Drugs in the Elderly (SHADES). $n$, number of patients; $25(\mathrm{OH}) \mathrm{D}_{3}$, 25-hydroxyvitamin $D_{3}$. 
Table 1 Baseline characteristics according to $25(\mathrm{OH}) \mathrm{D}_{3}$ quartiles. Data are presented as mean and S.D. or as percentages and ( $n$ ). Differences between groups were calculated with ANOVA and differences between proportions were calculated with $\chi^{2}$-test.

\begin{tabular}{|c|c|c|c|c|c|}
\hline & & Serum & $H) D_{3}$ quartile & & \\
\hline & 1 & 2 & 3 & 4 & $P$ value \\
\hline$n$ & 86 & 82 & 85 & 80 & \\
\hline $25(\mathrm{OH}) \mathrm{D}_{3}$ & & & & & \\
\hline Range (nmol/l) & $11-29$ & $30-37$ & $38-47$ & $48-120$ & \\
\hline Mean $(\mathrm{nmol} / \mathrm{l})$ & $24.1 \pm 4.1$ & $33.4 \pm 2.2$ & $42.1 \pm 2.8$ & $62.3 \pm 14.7$ & \\
\hline Male & $38 \%(n=33)$ & $23 \%(n=19)$ & $42 \%(n=36)$ & $24 \%(n=19)$ & NS \\
\hline Age (years) & $86.3 \pm 6.2$ & $84.7 \pm 6.8$ & $84.5 \pm 7.0$ & $84.3 \pm 7.2$ & NS \\
\hline Male & $85.8 \pm 6.4$ & $83.2 \pm 5.6$ & $81.9 \pm 7.4$ & $79.4 \pm 6.7$ & $P<0.01, \mathrm{Q} 1-\mathrm{Q} 4$ \\
\hline Female & $86.6 \pm 6.1$ & $85.2 \pm 7.1$ & $86.3 \pm 6.2$ & $85.8 \pm 6.8$ & NS \\
\hline Time in nursing home (years) & & & & & \\
\hline$<1$ & $48 \%(n=41)$ & $54 \%(n=44)$ & $55 \%(n=47)$ & $68 \%(n=54)$ & $P=0.05, \mathrm{Q} 1-\mathrm{Q} 4$ \\
\hline $1-3$ & $30 \%(n=26)$ & $22 \%(n=18)$ & $26 \%(n=22)$ & $16 \%(n=13)$ & NS \\
\hline$>3$ & $22 \%(n=19)$ & $24 \%(n=20)$ & $19 \%(n=16)$ & $16 \%(n=13)$ & NS \\
\hline BMI $\left(\mathrm{kg} / \mathrm{m}^{2}\right)$ & $24.6 \pm 4.5$ & $24.7 \pm 5.6$ & $25.9 \pm 5.1$ & $24.9 \pm 3.9$ & NS \\
\hline Male & $24.6 \pm 4.0$ & $25.4 \pm 3.8$ & $24.8 \pm 4.8$ & $24.9 \pm 3.8$ & NS \\
\hline Female & $24.6 \pm 4.8$ & $24.5 \pm 6.0$ & $26.7 \pm 5.2$ & $24.9 \pm 3.9$ & NS \\
\hline Haemoglobin (g/l) & $126.3 \pm 14.5$ & $125.0 \pm 14.8$ & $126.4 \pm 12.5$ & $125.4 \pm 14.2$ & NS \\
\hline Male & $127.8 \pm 15.0$ & $126.4 \pm 11.8$ & $128.6 \pm 13.5$ & $126.8 \pm 16.7$ & NS \\
\hline Female & $125.4 \pm 14.3$ & $124.5 \pm 15.6$ & $124.9 \pm 11.5$ & $125.0 \pm 13.6$ & NS \\
\hline Creatinine $(\mu \mathrm{mol} / \mathrm{l})$ & $79.0 \pm 30.0$ & $86.3 \pm 34.4$ & $98.9 \pm 64.5$ & $93.9 \pm 37.0$ & $P<0.05, \mathrm{Q} 1-\mathrm{Q} 3$ \\
\hline Male & $92.2 \pm 39.4$ & $101.0 \pm 43.4$ & $117.8 \pm 91.3$ & $106.5 \pm 55.0$ & NS \\
\hline Female & $70.8 \pm 18.2$ & $81.9 \pm 30.3$ & $84.8 \pm 25.8$ & $89.9 \pm 28.8$ & $\begin{array}{l}P<0.05, \mathrm{Q} 1-\mathrm{Q} 3 \\
\quad \text { and } 4\end{array}$ \\
\hline $\begin{array}{l}\text { GFR (estimated by cystatin C) } \\
\left(\mathrm{ml} / \mathrm{min} \text { per } 1.73 \mathrm{~m}^{2}\right)\end{array}$ & $62.4 \pm 25.4$ & $62.8 \pm 27.2$ & $56.0 \pm 24.6$ & $56.4 \pm 25.8$ & NS \\
\hline Male & $63.1 \pm 25.9$ & $60.8 \pm 26.4$ & $55.4 \pm 27.2$ & $56.3 \pm 20.8$ & NS \\
\hline Female & $62.0 \pm 25.3$ & $63.4 \pm 27.7$ & $56.4 \pm 22.8$ & $56.4 \pm 27.3$ & NS \\
\hline Systolic blood pressure $(\mathrm{mmHg})$ & $130.5 \pm 26.3$ & $130.3 \pm 23.6$ & $135.4 \pm 21.6$ & $135.9 \pm 23.1$ & NS \\
\hline Male & $128.2 \pm 26.9$ & $121.4 \pm 19.4$ & $126.2 \pm 18.2$ & $132.4 \pm 27.7$ & NS \\
\hline Female & $132.0 \pm 26.0$ & $132.7 \pm 24.2$ & $143.0 \pm 21.4$ & $137.0 \pm 21.6$ & NS \\
\hline Diastolic blood pressure $(\mathrm{mmHg})$ & $70.5 \pm 11.2$ & $71.7 \pm 11.4$ & $72.6 \pm 10.5$ & $73.4 \pm 11.6$ & NS \\
\hline Male & $71.5 \pm 9.7$ & $68.5 \pm 9.7$ & $71.5 \pm 9.2$ & $70.7 \pm 10.8$ & NS \\
\hline Female & $69.8 \pm 12.2$ & $72.6 \pm 11.7$ & $73.5 \pm 11.4$ & $74.2 \pm 11.8$ & NS \\
\hline $\begin{array}{l}\text { Frequency of patients with } \\
\text { hypertension diagnosis (\%) }\end{array}$ & $24 \%(n=21)$ & $28 \%(n=23)$ & $27 \%(n=23)$ & $40 \%(n=32)$ & NS \\
\hline Male & $36 \%(n=12)$ & $32 \%(n=6)$ & $22 \%(n=8)$ & $47 \%(n=9)$ & NS \\
\hline Female & $17 \%(n=9)$ & $27 \%(n=17)$ & $31 \%(n=15)$ & $38 \%(n=23)$ & NS \\
\hline $\begin{array}{l}\text { Frequency of patients with car- } \\
\text { diovascular diagnosis other } \\
\text { than hypertension }(\%)\end{array}$ & $55 \%(n=47)$ & $60 \%(n=49)$ & $60 \%(n=51)$ & $54 \%(n=43)$ & NS \\
\hline Male & $52 \%(n=17)$ & $68 \%(n=13)$ & $64 \%(n=23)$ & $53 \%(n=10)$ & NS \\
\hline Female & $57 \%(n=30)$ & $57 \%(n=36)$ & $57 \%(n=28)$ & $54 \%(n=33)$ & NS \\
\hline $\begin{array}{l}\text { Level of physical activity in the } \\
\text { modified Norton scale }\end{array}$ & & & & & \\
\hline Bedridden & - & - & - & - & NS \\
\hline Chairbound & $35 \%(n=30)$ & $25 \%(n=20)$ & $24 \%(n=20)$ & $23 \%(n=18)$ & NS \\
\hline Walks with help & $24 \%(n=21)$ & $17 \%(n=14)$ & $14 \%(n=12)$ & $15 \%(n=12)$ & NS \\
\hline Ambulant & $41 \%(n=35)$ & $58 \%(n=47)$ & $61 \%(n=51)$ & $63 \%(n=50)$ & NS \\
\hline
\end{tabular}

Significant differences are presented with $P$ values. $25(\mathrm{OH}) \mathrm{D}_{3}, 25$-hydroxyvitamin $\mathrm{D}_{3} ; n$, number of patients; NS, non-significant; $\mathrm{Q}$, quartile; GFR, glomerular filtration rate.

differences were seen between the quartiles in GFR estimated by cystatin C. For women who stayed $>1$ year in the nursing home a significant increase in body weight was seen 1 year after the first measurement at inclusion in the study, but otherwise no variation in body weight was noticed over time.
During the study period, 147 (44\%) of the 333 subjects died of any cause. The most common causes of death according to the death certificates were cardiovascular disease (48\%), infections (14\%), dementia (10\%), general organ failure (10\%), neoplastic disease (3\%), kidney failure (3\%) and other causes (12\%). The vitamin D levels in the 
Table 2 Outcome according to $25(\mathrm{OH}) \mathrm{D}_{3}$ quartiles, categorised from the baseline $25(\mathrm{OH}) \mathrm{D}_{3}$ levels. Data are presented as percentages and $(n)$. Differences between proportions were calculated with $\chi^{2}$-test.

Outcome
Death during the study
Incidence of fatal cardiovascular events
during the study (from death
certificates)
Incidence of nonfatal cardiovascular
events during 3 years (from medical
records)
Incidence of falls during 3 years
(from medical records)
Incidence of fractures during 3 years
(from medical records)
Incidence of falls from interview DFRI,
yes or no, at inclusion

\begin{tabular}{|c|c|c|c|c|}
\hline \multicolumn{4}{|c|}{ Serum $25(\mathrm{OH}) D_{3}$ quartile } & \multirow[b]{2}{*}{$P$ value } \\
\hline $1(n=86)$ & $2(n=82)$ & $3(n=85)$ & $4(n=80)$ & \\
\hline $\begin{array}{l}59 \%(n=51) \\
26 \%(n=22)\end{array}$ & $\begin{array}{l}44 \%(n=36) \\
21 \%(n=17)\end{array}$ & $\begin{array}{l}45 \%(n=38) \\
24 \%(n=20)\end{array}$ & $\begin{array}{l}28 \%(n=22) \\
14 \%(n=11)\end{array}$ & $\begin{array}{c}P<0.05, \mathrm{Q} 1-\mathrm{Q} 4 \\
\text { NS }\end{array}$ \\
\hline $9 \%(n=8)$ & $10 \%(n=8)$ & $18 \%(n=15)$ & $21 \%(n=17)$ & NS \\
\hline $8 \%(n=7)$ & $11 \%(n=9)$ & $15 \%(n=13)$ & $9 \%(n=7)$ & NS \\
\hline $13 \%(n=11)$ & $15 \%(n=12)$ & $14 \%(n=12)$ & $11 \%(n=9)$ & NS \\
\hline $69 \%(n=59)$ & $59 \%(n=48)$ & $65 \%(n=55)$ & $53 \%(n=42)$ & NS \\
\hline
\end{tabular}

Significant differences are presented with $P$ values. $25(\mathrm{OH}) \mathrm{D}_{3}, 25$-hydroxyvitamin $\mathrm{D}_{3} ; n$, number of patients; $\mathrm{Q}$, quartile; NS, non-significant; DFRI, Downton Fall Risk Index.

deceased subjects were lower at inclusion compared with the living subjects: $37.6 \mathrm{nmol} / 1$ compared with $42.2 \mathrm{nmol} / \mathrm{l}(P<0.01)$, as were the vitamin D levels from the last occasion of measuring: $35.3 \mathrm{nmol} / \mathrm{l}$ in the deceased subjects compared with $39.5 \mathrm{nmol} / \mathrm{l}$ in the living subjects $(P<0.05)$ with no significant differences between men and women. After a mean follow-up of 3 years, 59\% of the patients in Q1 had died compared with 28\% in Q4 (Table 2). The cumulative survival for the persons in the different vitamin D quartiles is shown in Fig. 2. HR (with 95\% CI) for mortality was $2.02(1.31-3.12)$ in Q1 compared with Q4 $(P<0.05), 2.03(1.32-3.14)$ in Q2 compared with Q4 $(P<0.05)$, and $1.6(1.03-2.48)$ in $\mathrm{Q} 3$ compared with Q4 $(P<0.05)$. In the analysis, we adjusted for differences in age, gender, BMI, systolic and diastolic blood pressure, GFR estimated from cystatin C, the season when the blood sample for vitamin D was collected, the time living in the nursing home, previous cardiovascular diseases, neoplastic diseases, dementia and the level of physical activity. Of these variables, only an increase in age and a limited level of physical activity were associated with a higher mortality risk in the Cox regression analyses. HR (with 95\% CI) for mortality was 1.06 (1.04-1.09) for age $(P<0.01)$. HR (with $95 \% \mathrm{CI}$ ) for mortality was 1.56 (1.12-2.17) in the group with physical activity level assessed as 2, who were chairbound (all day), and 1.88 (1.32-2.68) in the group with physical activity level assessed as 3, walks with help (wheelchair when independent transportations) compared with the group with physical activity level assessed as 4 , ambulant in the MNS $(P<0.01)$. There was a positive correlation between the levels of physical activity and the vitamin D levels, $r_{\mathrm{s}}=0.18(P=0.001)$.

The mean $25(\mathrm{OH}) \mathrm{D}_{3}$ concentration at inclusion was $40.2 \mathrm{nmol} / 1$ (s.D. 16.0), with no significant differences

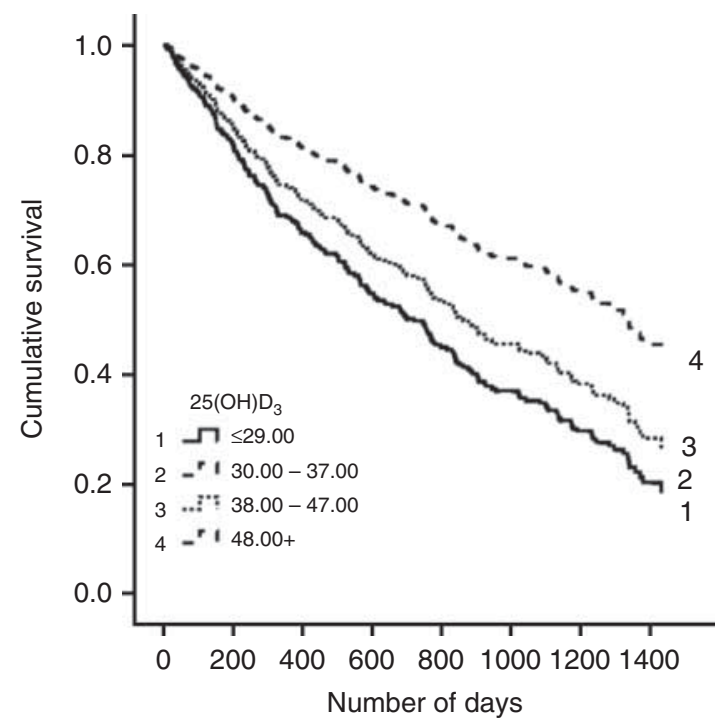

\section{Figure 2}

Cumulative survival according to $25(\mathrm{OH}) \mathrm{D}_{3}$ quartiles. Cox regression analyses were used to calculate $\mathrm{HR}$ for mortality in the different $25(\mathrm{OH}) \mathrm{D}_{3}$ quartiles with the fourth quartile as a reference. Compared with the subjects in $\mathrm{Q}_{4}\left(25(\mathrm{OH}) \mathrm{D}_{3}\right.$ $>48 \mathrm{nmol} / \mathrm{l}$ ), the HR (with $95 \% \mathrm{Cl}$ ) for mortality was 2.02 $(1.31-3.12)$ in Q1 $\left(25(\mathrm{OH}) \mathrm{D}_{3}<29 \mathrm{nmol} / \mathrm{l}\right)(P<0.05), 2.03$ $(1.32-3.14)$ in Q2 $\left(25(\mathrm{OH}) \mathrm{D}_{3} 30-37 \mathrm{nmol} / \mathrm{l}\right)(P<0.05)$ and 1.6 $(1.03-2.48)$ in Q3 $\left(25(\mathrm{OH}) \mathrm{D}_{3} 38-47 \mathrm{nmol} / \mathrm{l}\right)(P<0.05)$. 25(OH) $\mathrm{D}_{3}$, 25-hydroxyvitamin $D_{3} ; H R$, hazard ratio; $Q$, quartile. 
Table 3 Distribution of $25(\mathrm{OH}) \mathrm{D}_{3}$ at inclusion in elderly people in nursing homes. Data are presented as percentages and ( $n$ ). Differences between proportions were calculated with $\chi^{2}$-test.

\begin{tabular}{|c|c|c|c|}
\hline \multicolumn{4}{|c|}{ Serum $25(\mathrm{OH}) \mathrm{D}_{3}(\mathrm{nmol} / \mathrm{l})$} \\
\hline$<25$ & $26-50$ & $51-75$ & $>76$ \\
\hline $14.4 \%(n=48)$ & $65.8 \%(n=219)$ & $15.3 \%(n=51)$ & $4.5 \%(n=15)$ \\
\hline
\end{tabular}

\begin{tabular}{c}
\hline P value \\
\hline$P<0.001$, \\
columns $2-1,3$ and 4 \\
\hline
\end{tabular}

Significant differences are presented with $P$ values. $25(\mathrm{OH}) \mathrm{D}_{3}, 25$-hydroxyvitamin $\mathrm{D}_{3} ; n$, number of patients.

between men and women. Table 3 shows that $80 \%$ of the patients had $25(\mathrm{OH}) \mathrm{D}_{3}$ below $50 \mathrm{nmol} / \mathrm{l}$ and $14 \%$ a value below $25 \mathrm{nmol} / \mathrm{l}$.

The vitamin D levels decreased from the baseline to the second and third measurements. As expected, there were seasonal changes in the vitamin D level during the year. Higher values were seen from May until October, compared with November until April: 39.2 vs $35.7 \mathrm{nmol} / \mathrm{l}$ $(P<0.01)$, as illustrated in Fig. 3. In the analyses that compare the changes in vitamin $\mathrm{D}$ over time and with season, we used the vitamin $\mathrm{D}$ values from all three occasions of measuring. The times of the year for collections of the three blood samples were equivalently distributed.

When analysing the number of cardiovascular events, no significant differences between the quartiles of vitamin $\mathrm{D}$ were found, neither in the analysis of only nonfatal cardiovascular events nor when fatal cardiovascular events were included. In the analysis of the number of falls and fractures, the registered events were too few to allow statistical conclusions. No differences between the proportions of the vitamin D quartiles with cardiovascular events, fall events, fracture events or history of known falls according to interview with DFRI at inclusion were found (Table 2), but there was a difference in vitamin D levels in the female patients with a history of known falls compared with the female patients without history of known falls: 39.3 vs $44.7 \mathrm{nmol} / \mathrm{l}(P<0.05)$. No difference in vitamin D levels was seen between male patients with or without history of known falls.

\section{Discussion}

In this study, confined to subjects living in nursing homes without supplement with vitamin D in combination with calcium, we found that vitamin $\mathrm{D}$ deficiency was associated with an increased risk of mortality (Fig. 2). The risk of death during the observational time of 3 years was doubled in Q1 and Q2 compared with Q4. Also in Q3, the mortality risk was increased compared with Q4.
Increased age and reduced physical activity were also associated with an increased risk of mortality. The functional level might be of importance for the mortality risk in several ways, as a limited ability to move might be a consequence of other diseases and frailty, and might also lead to difficulties in spending time outdoors with limited sun exposure and affected vitamin D levels as a consequence.

Vitamin D deficiency was highly prevalent, as $80 \%$ of the study population had vitamin D levels below $50 \mathrm{nmol} / \mathrm{l}$. We found that the vitamin D levels changed over the year, with the highest values during the sunny months, which indicates the importance of sunlight on the vitamin $\mathrm{D}$ level. We found a decrease in vitamin $\mathrm{D}$ level over time, even though the women who had stayed in the nursing home $<1$ year gained weight during the first year. Vitamin D is stored in the adipose tissue, but the depot is not large enough to prevent seasonal changes in the plasma concentrations of $25(\mathrm{OH}) \mathrm{D}$ and PTH $(3,39)$. We had, however, no detailed information of the dietary calcium and vitamin D intake, other than that they all were served the same food at the nursing home. The possible reasons for the decline in vitamin D level might

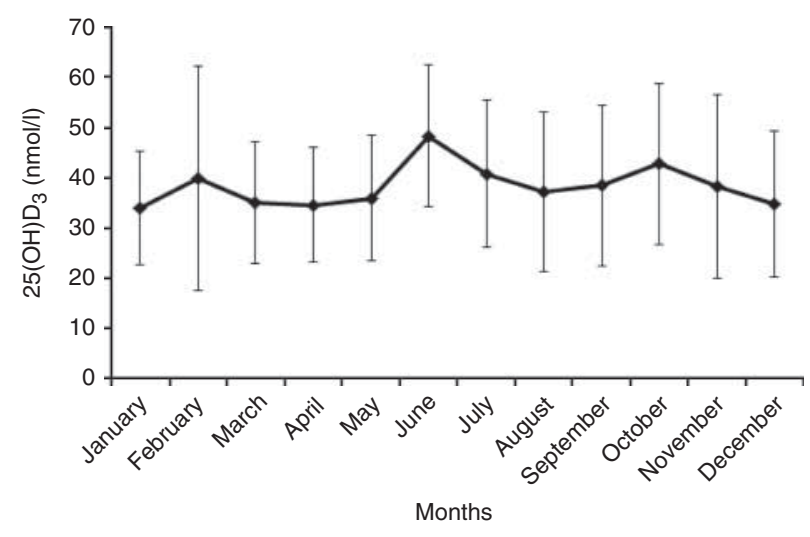

Figure 3

Seasonal changes in $25(\mathrm{OH}) \mathrm{D}_{3}$ in elderly people in nursing homes, presented as mean $25(\mathrm{OH}) \mathrm{D}_{3} \pm$ s.D. $25(\mathrm{OH}) \mathrm{D}_{3}$, 25-hydroxyvitamin $D_{3}$. 
be an impairment of the general condition, progression of chronic diseases or reduced sun exposure after moving into the nursing home, but this question remains to be answered in future studies.

No differences were found between the proportions of the vitamin D quartiles with a history of known falls, but the difference in vitamin $\mathrm{D}$ levels was significant for women. No association was seen between the vitamin D levels and the risk of cardiovascular events. The number of registered falls and fractures was too few to allow any conclusions about its association with the vitamin D levels. Thus, in this study, we cannot explain the mechanisms by which low vitamin D levels are associated with an increased risk of mortality. As the study is an observational study, we cannot rule out the possibility that low levels of vitamin D are not a cause of the mortality but an effect of other diseases.

The strength of this study is that elderly individuals in nursing homes were included and followed prospectively. This is a population category that has not been particularly well-studied previously. The elderly in nursing homes often have a high morbidity, which was evident also in this study with a total mortality of $44 \%$ during the study period. Another strength of this study is that the vitamin D levels were measured repeatedly, allowing comparison over time. In spite of the high mortality among the subjects, there was a heterogeneity in the disease panorama which made the number of reported events in each category relatively few. We had to rely on the medical records for the analysis of the events, and there might be a variation in documentation by different health care providers. There was, for example, a discrepancy between documented falls in the medical records and the history of falls according to interview. Cause of death was obtained from death certificates and these may in many cases be inaccurate. However, the Swedish Cause of Death Register has been known for maintaining high international standards of accuracy (40), showing that data on malignant neoplasms and ischemic heart disease generally are reliable (41). A variation in documentation might have contributed to the lack of clear explanation to our not being able to see any univocal explanation to the increased mortality in the people with low vitamin D levels. The observational design of this study precludes any conclusions about causality, but the clear association between low vitamin D levels and mortality calls for randomised clinical trials exploring the effects of vitamin D supplementation in elderly institutionalised subjects. A limitation of the study is that the blood samples were collected with a 1-year interval and there is a risk that the blood samples were collected from the people with high vitamin D values during summer. This is unlikely, however, as the method of selection was the same.

Our main finding that vitamin D deficiency in elderly people living in nursing homes was associated with an increased mortality risk is in line with a study on institutionalised female patients in Austria (23). Several studies on non-institutionalised elderly have also shown a relationship between vitamin $\mathrm{D}$ deficiency and increased mortality $(16,17,18,19,20,21,22)$. A meta-analysis of prospective observational studies shows that the mortality risk decreases when the vitamin D level rises, with optimal concentrations around $75-87.5 \mathrm{nmol} / \mathrm{l}$ (15), which are higher values than in our fourth quartile. In contrast, in a study carried out in community-dwelling American men of at least 65 years old, no association was found between low vitamin $\mathrm{D}$ levels and an increased risk of mortality (42). However, the vitamin D levels were generally higher and in their study only the first quartile had a vitamin D level below $50 \mathrm{nmol} / \mathrm{l}$.

In conclusion, vitamin D deficiency has been found to be highly prevalent and has been associated with an increased risk of mortality in elderly people in nursing homes in Sweden. Our results correspond with the results of other international observational studies. There is a need for new strategies and routines to prevent and maybe treat vitamin $\mathrm{D}$ deficiency in the elderly in nursing homes, and the potential benefits of vitamin $\mathrm{D}$ supplementation need to be evaluated in randomised clinical trials.

Declaration of interest

The authors declare that there is no conflict of interest that could be perceived as prejudicing the impartiality of the research reported.

\section{Funding}

Financial support was provided by the County Councils of Jönköping, Östergötland and Region Skåne, Sweden.

\section{Author contribution statement}

S Mölstad, C J Östgren and P Midlöv contributed in study concept and design, $C$ Lannering in acquisition of data, M Samefors, C J Östgren and $A$ Tengblad in analysis and interpretation of the data, and M Samefors and A Tengblad in drafting of the manuscript. Critical revision of the manuscript for important intellectual content was done by A Tengblad, C J Östgren, S Mölstad and P Midlöv.

\section{Acknowledgements}

The authors thank County Councils of Jönköping, Östergötland and Region Skåne, Sweden for the financial assistance provided. 


\section{References}

1 Perez-Lopez FR, Chedraui P \& Fernandez-Alonso AM. Vitamin D and aging: beyond calcium and bone metabolism. Maturitas 201169 27-36. (doi:10.1016/j.maturitas.2011.02.014)

2 Webb AR, Kline L \& Holick MF. Influence of season and latitude on the cutaneous synthesis of vitamin $\mathrm{D}_{3}$ : exposure to winter sunlight in Boston and Edmonton will not promote vitamin $\mathrm{D}_{3}$ synthesis in human skin. Journal of Clinical Endocrinology and Metabolism 198867 373-378. (doi:10.1210/jcem-67-2-373)

3 Brot C, Vestergaard P, Kolthoff N, Gram J, Hermann AP \& Sorensen OH. Vitamin D status and its adequacy in healthy Danish perimenopausal women: relationships to dietary intake, sun exposure and serum parathyroid hormone. British Journal of Nutrition 200186 97-103. (doi:10.1079/BJN2001345)

4 Mosekilde L. Vitamin D and the elderly. Clinical Endocrinology 200562 265-281. (doi:10.1111/j.1365-2265.2005.02226.x)

5 van Schoor NM, Visser M, Pluijm SM, Kuchuk N, Smit JH \& Lips P. Vitamin D deficiency as a risk factor for osteoporotic fractures. Bone 200842 260-266. (doi:10.1016/j.bone.2007.11.002)

6 Sakuma M, Endo N \& Oinuma T. Serum 25-OHD insufficiency as a risk factor for hip fracture. Journal of Bone and Mineral Metabolism 200725 147-150. (doi:10.1007/s00774-007-0749-9)

7 Ikegami S, Kamimura M, Uchiyama S \& Kato H. Women with insufficient 25-hydroxyvitamin D without secondary hyperparathyroidism have altered bone turnover and greater incidence of vertebral fractures. Journal of Orthopaedic Science 201116 573-580. (doi:10.1007/ s00776-011-0107-6)

8 Lopes JB, Danilevicius CF, Takayama L, Caparbo VF, Scazufca M, Bonfa E \& Pereira RM. Vitamin D insufficiency: a risk factor to vertebral fractures in community-dwelling elderly women. Maturitas 200964 218-222. (doi:10.1016/j.maturitas.2009.09.020)

9 Stein MS, Wark JD, Scherer SC, Walton SL, Chick P, Di Carlantonio M, Zajac JD \& Flicker L. Falls relate to vitamin D and parathyroid hormone in an Australian nursing home and hostel. Journal of the American Geriatrics Society 199947 1195-1201.

10 Kendrick J, Targher G, Smits G \& Chonchol M. 25-Hydroxyvitamin D deficiency is independently associated with cardiovascular disease in the Third National Health and Nutrition Examination Survey. Atherosclerosis 2009205 255-260. (doi:10.1016/j.atherosclerosis.2008.10.033)

11 Anderson JL, May HT, Horne BD, Bair TL, Hall NL, Carlquist JF, Lappé D \& Muhlestein JB, for the Intermountain Heart Collaborative (IHC) Study Group. Relation of vitamin D deficiency to cardiovascular risk factors, disease status, and incident events in a general healthcare population. American Journal of Cardiology 2010106 963-968. (doi:10.1016/j.amjcard.2010.05.027)

12 Kim DH, Sabour S, Sagar UN, Adams S \& Whellan DJ. Prevalence of hypovitaminosis D in cardiovascular diseases (from the National Health and Nutrition Examination Survey 2001 to 2004). American Journal of Cardiology 2008102 1540-1544. (doi:10.1016/j.amjcard. 2008.06.067)

13 Lim S, Shin H, Kim MJ, Ahn HY, Kang SM, Yoon JW, Choi SH, Kim KW, Song JH, Choi SI et al. Vitamin D inadequacy is associated with significant coronary artery stenosis in a community-based elderly cohort: the Korean Longitudinal Study on Health and Aging. Journal of Clinical Endocrinology and Metabolism 201297 169-178. (doi:10.1210/jc. 2011-1580)

14 Steinvil A, Leshem-Rubinow E, Berliner S, Justo D, Finn T, Ish-shalom M, Birati EY, Shalev V, Sheinberg B \& Rogowski O. Vitamin D deficiency prevalence and cardiovascular risk in Israel. European Journal of Clinical Investigation 201141 263-268. (doi:10.1111/j.1365-2362. 2010.02403.x)

15 Zittermann A, Iodice S, Pilz S, Grant WB, Bagnardi V \& Gandini S. Vitamin D deficiency and mortality risk in the general population: a meta-analysis of prospective cohort studies. American Journal of Clinical Nutrition 201295 91-100. (doi:10.3945/ajcn.111.014779)
16 Dobnig H, Pilz S, Scharnagl H, Renner W, Seelhorst U, Wellnitz B, Kinkeldei J, Boehm BO, Weihrauch G \& Maerz W. Independent association of low serum 25-hydroxyvitamin D and 1.25-dihydroxyvitamin D levels with all-cause and cardiovascular mortality. Archives of Internal Medicine 2008168 1340-1349. (doi:10.1001/ archinte.168.12.1340)

17 Strand Hutchinson M, Grimnes G, Joakimsen RM, Figenschau Y \& Jorde R. Low serum 25-hydroxyvitamin D levels are associated with increased all-cause mortality risk in a general population: the Tromso study. European Journal of Endocrinology 2010162 935-942. (doi:10.1530/EJE-09-1041)

18 Virtanen JK, Nurmi T, Voutilainen S, Mursu J \& Tuomainen T-P. Association of serum 25-hydroxyvitamin D with the risk of death in a general older population in Finland. European Journal of Nutrition 2011 50 305-312. (doi:10.1007/s00394-010-0138-3)

19 Pilz S, Dobnig H, Nijpels G, Heine RJ, Stehouwer CD, Snijder MB, van Dam RM \& Dekker JM. Vitamin D and mortality in older men and women. Clinical Endocrinology 200971 666-672. (doi:10.1111/j.13652265.2009.03548.x)

20 Ginde AA, Scragg R, Schwartz RS \& Camargo CA. Prospective study of serum 25-hydroxyvitamin D level, cardiovascular disease mortality, and all-cause mortality in older U.S. adults. Journal of the American Geriatrics Society 200957 1595-1603. (doi:10.1111/j.1532-5415.2009.02359.x)

21 Semba RD, Houston DK, Ferrucci L, Cappola AR, Sun K, Guralnik JM \& Fried LP. Low serum 25-hydroxyvitamin D concentrations are associated with greater all-cause mortality in older communitydwelling women. Nutrition Research 200929 525-530. (doi:10.1016/ j.nutres.2009.07.007)

22 Semba RD, Houston DK, Bandinelli S, Sun K, Cherubini A, Cappola AR, Guralnik JM \& Ferrucci L. Relationship of 25-hydroxyvitamin D with all-cause and cardiovascular disease mortality in older communitydwelling adults. European Journal of Clinical Nutrition 201064 203-209. (doi:10.1038/ejcn.2009.140)

23 Pilz S, Dobnig H, Tomaschitz A, Kienreich K, Meinitzer A, Friedl C, Wagner D, Piswanger-Sölkner C, März W \& Fahrleitner-Pammer A. Low 25-hydroxyvitamin $\mathrm{D}$ is associated with increased mortality in female nursing home residents. Journal of Clinical Endocrinology and Metabolism 201297 E653-E657. (doi:10.1210/jc.2011-3043)

24 Bjelakovic G, Gluud LL, Nikolova D, Whitfield K, Wetterslev J, Simonetti RG, Bjelakovic M \& Gluud C. Vitamin D supplementation for prevention of mortality in adults. Cochrane Database of Systematic Reviews 20117 CD007470. (doi:10.1002/14651858.CD007470.pub2)

25 Dror Y, Giveon SM, Hoshen M, Feldhamer I, Balicer RD \& Feldman BS Vitamin D levels for preventing acute coronary syndrome and mortality: evidence of a nonlinear association. Journal of Clinical Endocrinology and Metabolism 201398 2160-2167. (doi:10.1210/jc. 2013-1185)

26 Eisman JA. When is a U-curve actually a J-curve? Is it really too much of a good thing. Journal of Clinical Endocrinology and Metabolism 201398 1863-1864. (doi:10.1210/jc.2013-1890)

27 Lips P. Vitamin D deficiency and secondary hyperparathyroidism in the elderly: consequences for bone loss and fractures and therapeutic implications. Endocrine Reviews 200122 477-501. (doi:10.1210/edrv.22. 4.0437)

28 Humble M. D-vitaminbrist kanske vanligare än vi trott. Lakartidningen $200711853-857$.

29 Holick MF. McCollum Award Lecture, 1994: vitamin D - new horizons for the 21st century. American Journal of Clinical Nutrition $1994 \mathbf{6 0}$ 619-630.

30 Sem SW, Sjoen RJ, Trygg K \& Pedersen JI. Vitamin D status of two groups of elderly in Oslo: living in old people's homes and living in own homes. Comprehensive Gerontology. Section A, Clinical and Laboratory Sciences 19871 126-130.

31 Toss G, Almqvist S, Larsson L \& Zetterqvist H. Vitamin D deficiency in welfare institutions for the aged. Acta Medica Scandinavica 1980208 87-89. (doi:10.1111/j.0954-6820.1980.tb01157.x) 
32 Gloth FM III, Gundberg CM, Hollis BW, Haddad JG \& Tobin JD. Vitamin D deficiency in homebound elderly persons. Journal of the American Medical Association 1995274 1683-1686. (doi:10.1001/jama. 1995.03530210037027)

33 Liu BA, Gordon M, Labranche JM, Murray TM, Vieth R \& Shear NH. Seasonal prevalence of vitamin D deficiency in institutionalized older adults. Journal of the American Geriatrics Society 199745 598-603.

34 Sambrook PN, Cameron IA, Cumming RG, Lord SR, Schwarz JM, Trube A \& March LM. Vitamin D deficiency is common in frail institutionalised older people in northern Sydney. Medical Journal of Australia 2002176560.

35 Perez-Llamas F, Lopez-Contreras MJ, Blanco MJ, Lopez-Azorin F, Zamora S \& Moreiras O. Seemingly paradoxical seasonal influences on vitamin D status in nursing-home elderly people from a Mediterranean area. Nutrition 200824 414-420. (doi:10.1016/j.nut.2008.01.006)

36 Ek AC, Unosson M \& Bjurulf P. The modified Norton scale \& the nutritional state. Scandinavian Journal of Caring Sciences 19893 183-187. (doi:10.1111/j.1471-6712.1989.tb00290.x)

37 Downton JH. In Falls in the Elderly. London, UK: Edward Arnold, 1993.

38 Grubb A, Nyman U, Bjork J, Lindstrom V, Rippe B, Sterner G \& Christensson A. Simple cystatin C-based prediction equations for glomerular filtration rate compared with the modification of diet in renal disease prediction equation for adults and the Schwartz and the
Counahan-Barratt prediction equations for children. Clinical Chemistry 200551 1420-1431. (doi:10.1373/clinchem.2005.051557)

39 Krall EA, Sahyoun N, Tannenbaum S, Dallal GE \& Dawson-Hughes B. Effect of vitamin D intake on seasonal variations in parathyroid hormone secretion in postmenopausal women. New England Journal of Medicine 1989321 1777-1783. (doi:10.1056/NEJM 198912283212602)

40 Nyström L, Larsson LG, Rutqvist LE, Lindgren A, Lindqvist M, Rydén S, Andersson I, Bjurstam N, Fagerberg G, Frisell J et al. Determination of cause of death among breast cancer cases in the Swedish randomized mammography screening trials. A comparison between official statistics and validation by an endpoint committee. Acta Oncologica 199534 145-152. (doi:10.3109/02841869509093948)

41 Johansson LA, Björkenstam C \& Westerling R. Unexplained differences between hospital and mortality data indicated mistakes in death certification: an investigation of 1,094 deaths in Sweden during 1995. Journal of Clinical Epidemiology 200962 1202-1209. (doi:10.1016/ j.jclinepi.2009.01.010)

42 Cawhton PM, Parimi N, Barrett-Connor E, Laughlin GA, Ensrud KE, Hoffman AR, Shikany JM, Cauley JA, Lane NE, Bauer DC et al. Serum 25-hydroxyvitamin D, parathyroid hormone, and mortality in older men. Journal of Clinical Endocrinology and Metabolism 201095 4625-4634. (doi:10.1210/jc.2010-0638)

Received 20 October 2013

Revised version received 5 February 2014

Accepted 11 February 2014 